\title{
Correction to: Economic evaluation of AbobotulinumtoxinA vs OnabotulinumtoxinA in real-life clinical management of cervical dystonia
}

\author{
V. P. Misra ${ }^{1}$, N. Danchenko ${ }^{2 *}$, P. Maisonobe ${ }^{2}$, J. Lundkvist ${ }^{3}$ and M. Hunger ${ }^{4}$
}

\author{
Correction to: J Clin Mov Disord 7, 2 (2020) \\ https://doi.org/10.1186/s40734-020-0083-0
}

Following publication of the original article [1], an error was identified in the Cost-per-responder sub-section.

The updated conclusion is given below and the changes have been highlighted in bold typeface.

The results showed that the adjusted mean total costper-responder was lower for patients receiving aboBoNTA compared to patients receiving onaBoNT-A (€986 vs. $€ 1524)$, based on the primary treatment response definition.

\section{Author details}

${ }^{1}$ Imperial College Healthcare NHS Trust, London, UK. ${ }^{2}$ Ipsen, Boulogne-

Billancourt, France. ${ }^{3}$ Ipsen, Stockholm, Sweden. ${ }^{4}$ ICON plc, Munich, Germany.

Published online: 29 July 2020

\section{Reference}

1. Misra VP, Danchenko N, Maisonobe P, et al. Economic evaluation of

AbobotulinumtoxinA vs OnabotulinumtoxinA in real-life clinical management

of cervical dystonia. J Clin Mov Disord. 2020;7:2 https://doi.org/10.1186/s40734020-0083-0.

The original article can be found online at https://doi.org/10.1186/s40734 020-0083-0.

* Correspondence: natalya.danchenko@ipsen.com

IIpsen, Boulogne-Billancourt, France

Full list of author information is available at the end of the article

(c) The Author(s). 2020 Open Access This article is licensed under a Creative Commons Attribution 4.0 International License, which permits use, sharing, adaptation, distribution and reproduction in any medium or format, as long as you give appropriate credit to the original author(s) and the source, provide a link to the Creative Commons licence, and indicate if changes were made. The images or other third party material in this article are included in the article's Creative Commons licence, unless indicated otherwise in a credit line to the material. If material is not included in the article's Creative Commons licence and your intended use is not permitted by statutory regulation or exceeds the permitted use, you will need to obtain permission directly from the copyright holder. To view a copy of this licence, visit http://creativecommons.org/licenses/by/4.0/. The Creative Commons Public Domain Dedication waiver (http://creativecommons.org/publicdomain/zero/1.0/) applies to the data made available in this article, unless otherwise stated in a credit line to the data. 